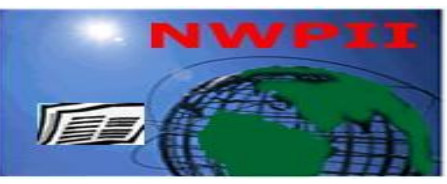

American Journal of Biomedical Sciences

ISSN: 1937-9080

nwpii.com/ajbms

\title{
Dengue Virus Serotype 2 (DEN-2) is Common in Pakistan
}

\author{
Tauseef Ahmad*
}

Department of Microbiology, Hazara University, Mansehra, Khyber Pakhtunkhwa, Pakistan

*Corresponding Author

Tauseef Ahmad

Shah Abad, Ouch 18750

Dir (Lower), Khyber Pakhtunkhwa

Pakistan

Mobile: +92-346-9403966

E-mail: hamdardmicrobiologist@gmail.com

Received: 7 November 2013; | Revised: 24 November 2013; | Accepted: 8 December 2013

Keywords: Outbreak, Dengue virus, Flaviviridae, Dengue Hemorrhagic Fever.

\section{EDITORIAL}

The aim of this editorial is to explore the outbreaks cause by different serotypes of dengue virus (DENV) in Pakistan in the past and also updates the epidemiology of dengue in Pakistan. In the preparation of this editorial various published literatures have been reviewed from international and national journals, local newspapers and books. Currently the Dengue is one of the most serious public health problem worldwide; especially in tropical and subtropical regions of the world [1-2]. Dengue is caused by arthropod-borne small spherical, single-stranded enveloped RNA virus known as dengue virus (DENV) belongs to family Flaviviridae and genus Flavivirus. The DENV infect mammalian and vector cells [3]. The four known serotypes of DENV cause the disease include dengue virus-1 (DEN-1), dengue virus-2 (DEN-2), dengue virus
(DEN-3) and dengue virus-4 DEN-4. All the four serotypes have been identified from different regions of the world [4-5].

According to World Health Organization (WHO), about 50-100 million cases of dengue fever and 500,000 cases of Dengue Hemorrhagic Fever (DHF) are reported annually along with 24,000 deaths [6]. The dengue is endemic more than 100 countries. The most serious affected regions are South-east Asia and the Western Pacific. The WHO, declares dengue fever and (DHF) are endemic in South Asia. In America, more than 890,000 cases of dengue of which 26 000 cases were DHF reported in 2007. More than $70 \%$ cases of dengue fever Asia and the Pacific regions of the world followed by America, Middle East and Africa [7].

The first epidemic of dengue in Pakistan was reported in 1994. In Pakistan many epidemic of dengue occurred in the last twenty years [7-14]. The major epidemic of dengue is occurred in 
2011, in Lahore, Punjab province of Pakistan [1516]. In Pakistan the serotype DEN-2 is the most common among the other serotypes. A study conducted by Muhammad et al., [17] in Pakistan reported that $96.02 \%$ cases of dengue caused by serotype DEN-2 in the 2011 epidemic in Lahore, Punjab province, Pakistan. The study conducted by Fatima et al., [1] in Pakistan reported that DEN-2 and DEN-3 serotypes are the causative agent of 2006-2009 outbreaks in Pakistan. In others studies conducted in Pakistan shows that the serotypes DEN-1, DEN-3 and DEN-4 are also found. According to Humayoun et al., [14] reported DEN4, DEN2, and DEN3 serotypes from Pakistan, the results shows that the DEN-4 is predominant serotype. Currently the dengue outbreak is occurred in district Swat, province Khyber Pakhtunkhwa, Pakistan in August, 2013, infected more than seven thousand of peoples in Swat district. The cases of dengue were also identified in the adjacent area of Swat, known district Dir (Lower) and Batkhela, Malakand Agency [18-20]. We recommended further studies in this regards in district Swat, Pakistan.

\section{Acknowledgments}

The author declares that they have no competing interest.

\section{References}

1. Fatima, Z.; Idrees, M.; Bajwa, M. A.; Tahir, Z.; Ullah, O.; Zia M. Q. Serotype and genotype analysis of dengue virus by sequencing followed by phylogenetic analysis using samples from three mini outbreaks-20072009 in Pakistan, BMC Microbiol, 2011, 10(11), 200; doi: 10.1186/1471-2180-11-200.

2. WHO. Dengue and dengue hemorrhagic fever: WHO fact sheet 117. World Health Organization, Geneva, Switzerland, 2002.

3. Halstead, S. B. Antibody, macrophages, dengue virus infection, shock, and hemorrhage a pathogenetic cascade, Rev Infect Dis, 1989, 11(4):S830-S839.
4. White, N. J. Variation in virulence of dengue virus, Lancet, 1999, 354-1401; doi: 10.1016/S0140-6736(99)00236-6.

5. WHO. Cost and burden of dengue and chikungunya from the Americas to Asia. Dengue Bulletin - 2011, 2010, 34.

6. Dengue Fever World Health Organization Fact Sheet No. 117, WHO, 2009. [http://www.who.int/mediacentre/factsheets/f s117/en/].

7. WHO. Dengue in Africa: emergence of DENV-3. Weekly Epidemiological Record, 2009, 84(11/12): 85-96.

8. Haye, C. G.; Baqar, S.; Ahmed, T.; Chowdhry, M. A.; Reisen, W. K. West Nile virus in Pakistan: Sero-epidemiological studies in Punjab Province, Trans R Soc Trop Med Hyg, 1982, 76, 431-36; doi. 10.1016/0035-9203(82) 90130-4.

9. Chan, Y. C.; Salahuddin, N. I.; Khan, J.; Tan, H. C.; Seah, C. L.; Li, J.; Chow, V. T. Dengue haemorrhagic fever outbreak in Karachi, Pakistan, 1994, Trans $R$ Soc Trop Med Hyg, 1995, 89, 619-20; doi: 10.1016/0035-9203(95) 90412-3.

10. Paul, R. E.; Patel, A. Y.; Mirza, S.; FisherHoch, S. P.; Luby, S. P. Expansion of epidemic dengue viral infections to Pakistan, Int J Infect Dis, 1998, 2, 197-201; doi. 10.1016/S1201-9712 (98)90052-2.

11. Akram, D. S.; Igarashi, A.; Takasu, T. Dengue virus infection among children with undifferentiated fever in Karachi, Indian $J$ Pediatr, 1998, 65, 735-740.

12. Khan, E.; Siddiqui, J.; Shakoor, S.; Mehraj, V.; Jamil, B.; Hassan, R. (2007). Dengue outbreak in Karachi, Pakistan, 2006: experience at a tertiary care centre, $T$ Roy Soc Trop Med H, 2007, 101, 1114-1119; doi: 10.1016/j.trstmh. 2007.06.016.

13. Jamil, B.; Hasan, R.; Zafar, A.; Bewley, K.; Chamberlain, J.; Mioulet, V.; Rowlands, M.; Hewson, R. Dengue virus serotype 3, Karachi, Pakistan, Emerg Infect Dis, 2007, 13 (1), 182183.

14. Humayoun, M. A.; Waseem, T.; Jawa A. A.; Hashimi, M. S.; Akram, J. Multiple dengue serotypes and high frequency of dengue hemorrhagic fever at two tertiary care 
hospitals in Lahore during the 2008 dengue virus outbreak in Punjab, Pakistan, Int J Infect Dis, 2010, 14 (Suppl 3), 54-59.

15. Park, K. Park's textbook of preventive and social medicine, 20th Ed, Bhanot B: Bhanot, 2009.

16.

Health.

http://www.thenews.com.pk/NewsDetail.aspx $? I D=23989$.

17. Muhammad, I.; Waqar, H.; Habib, U. R.; Ghias U. N. T.; Samia, A.; Zareen, F.; Madiha A.; Syed, M. R.; Liaqat, A.; Abrar, H.; Iram, A.; Muhammad, S.; Bushra, K.; Sana, S.; Bilal, N.; Asfand, T.; Muhammad, W.; Muhammad, W. Dengue Virus Serotype 2 (DEN-2): the Causative Agent of 2011Dengue Epidemic in Pakistan, Am. J.
Biomed. Sci, 2012, 4(4), 307-315; doi: 10.5099/aj120400307; ISSN: 1937-9080: nwpii.com/ajbms

18. The Nation. Dengue, (September, 2013). http://www.nation.com.pk/dengue

19. Bureau report. Daily express Islamabad, (September, 2013), $13 \quad$ (100), 8. http://www.dailyexpress.com.pk

20. Humanitarian Bulletin Pakistan. (October, 2013), Issue 19 | 16 September - 15 October 2013. 